\title{
The Frenchness of Marcel Lefebvre and the Society of St Pius X:
}

\section{a new reading}

Brian Sudlow, Aston University

\section{ABSTRACT}

The case of Marcel Lefebvre and the SSPX deserves fresh perspectives. The current historiography is too franco-centric, focused on selective aspects of Lefebvre's biography and the actions of isolated individuals, rather than with the life of the SSPX itself. After evaluating the current state of the historiography, this article proposes a new analysis of the SSPX's political discourses in France and internationally and undertakes to reframe the relationship between Lefebvre's life and his congregation by re-examining his African missionary experiences. Such new perspectives will be helpful as the SSPX moves towards regularisation under the pontificate of Pope Francis.

\section{KEYWORDS}

SSPX, Marcel Lefebvre, Action française, far right, missionary Catholicism, Pope Francis

The Society of St Pius X (hereafter, the SSPX) is one of the most controversial religious organisations of French origin over the last fifty years. Rejecting many of the reforms of the Second Vatican Council (1962-65), it has risen from a minor irritation to Vatican sensibilities in the 1970s, to being the focus of a concerted reconciliation project supported by the last two popes. If, therefore, its significance 
is beyond question, the meaning of its French origins, their importance and their influence have been the subject of constant evolution albeit largely homogenous critical judgment. This article aims to bring a fresh assessment of these matters to the academy's attention, as official reconciliation attempts intensify under Pope Francis.

The history of the SSPX is easily summarised. It is a religious congregation of priests who live without vows, founded in 1970 by Archbishop Marcel Lefebvre (1905-1991). The SSPX lost its canonical approval in 1975 and Archbishop Lefebvre was suspended from his ministry in 1976, ultimately for contesting new agendas set by the Second Vatican Council concerning worship, relations with other religions and the position of the Church towards the State. In June 1988 relations soured further when the aging French prelate ordained four bishops against Rome's orders. Lefebvre, another bishop who assisted him, and the four men they made into bishops, had committed a 'schismatic act' and thereby incurred automatic excommunication (John Paul II, 1988). Lefebvre died in 1991, disputing the excommunication and unreconciled with Rome but feted as a hero and a saint by his followers.

A brief overview of important landmarks in the current historiography reveals the wide critical consensus about this slice of history. On the Anglophone side, Colin Robert's account (2000: 273) of the Lefebvrist movement sees it 'primarily as a religious phenomenon'. Roberts's summary of the SSPX's theology is unusually thorough and competent. Nevertheless, while he admits that it does have political dimensions, notably an association with the Front National, these discrete categories and his explanations of Lefebvre's doctrine would leave one thinking that Lefebvre's 
anxieties are entirely conditioned by their French context, a position this article will strongly contest. Writing nearly ten years earlier, Van Der Krogt (1992) ranks the SSPX alongside tiny Catholic fundamentalist groups like the weird and wacky Palmerian Catholic Church. While it is true that one of Lefebvre's seminary professors became entangled with the Palmerians, this kind of assessment looks a little wild now, even if the importance of the Lefebvrist case would only become more obvious after the millennium (Celier, 2007). In a different mode, Pierre Birnbaum (2006), writing in English for once, portrays the SSPX as a religious acolyte of the Front National, apparently reducing the character of the Lefebvrists to the actions of a few priests in the admittedly important French district. These soundings taken of the historiography in English leave us with a very clear critical consensus: the SSPX are religious oddballs or simply political extremists.

Among critics writing in French the major lines of the historiography are traced by the Dominican theologian Yves Congar (1976), historian Emile Poulat (1985) and Catholic intellectual and political scientist René Rémond (1989), who all tend to see the Lefebvrist movement (though not always Lefebvre himself) as protestaire. More recently Philippe Levillain (2010) launched a sometimes excoriating attack on the SSPX; an attack whose long list of embarrassing inaccuracies was exposed by SSPX priest and philosopher Grégoire Celier (2010). More reliable though less expansive, Florian Michel (2009) sees the movement as an 'antiromanisme ultraromain'. If space does not here allow a richer exploration of these critics, their general tendency is summarised with ease. As with the Anglophone historiography, French critics see the SSPX either as a backward religious movement or else the agent of unpleasant political nostalgia. In their view, 
therefore, it would appear the SSPX is neither particularly Catholic, nor perhaps authentically French.

The need to revisit this question arises from factors seen in the last ten years and which cause particular anxiety in France. First, Benedict XVI's 2007 letter Summorum Pontificum, permitting the widespread use of the traditional Latin ceremonies of the Church (in near-universal use until 1969), had the effect of decontaminating, and thereby invigorating, support for the pre-conciliar liturgy. Furthermore, the SSPX now accounts for about $10 \%$ of French ordinands to the priesthood, and most of those $10 \%$ are in their early-to-mid $20 \mathrm{~s}$. In a context where priestly ordinations run nationally at less than 100 a year, and in which the median age of French priests now stands over 75 (Hoffner and De Gaulmyn, 2010), the SSPX in tandem with officially approved traditional congregations - notably the Fraternity of St Peter, the Institute of Christ the King, and the Institute of the Good Shepherd offers a tangible injection of traditionally orientated youth into the French clergy. In 2015 figures showed that of the 652 priests ordained in France since 2009, 19\% of the total (107) exclusively celebrate the traditional rites (Nardi: 2015). When these factors are combined with the traditionalist trends towards religiously endogamous marriage, at least in France (Rostand, 2015), and higher birth rates than other Catholics, it is likely that the SSPX could play an increasingly important role in the future of French Catholicism. Most surprising of all, Pope Francis in a letter announcing the jubilee Year of Mercy 2015-16, unilaterally conferred canonical jurisdiction on the priests of the SSPX to hear confessions from 8 December 2015 onwards. Such a burgeoning of the SSPX's canonical legitimacy will pose new dilemmas for the Church in France, not least because of the baggage that comes 
inevitably with the SSPX's most notorious label of intégriste (CICAD, 2013; Libération, 2012).

In the light of these new factors, this article aims to set out a fresh rereading of the SSPX and Lefebvre's heritage, especially reassessing the importance of French influences in the congregation's history. It thus raises the question of whether the importance of Lefebvre's political leanings and hinterland in shaping the movement has been correctly assessed. It will do this by evaluating Florian Michel's chapter 'L'Action française et l'intégrisme catholique: les paradoxes d'un antiromanisme ultraromain' which gathers together many of the common arguments about the character of Lefebvre's congregation. To underpin the evaluation of such published sources, this article's author interviewed five individuals associated with the SSPX: Father Christian Bouchacourt (current superior of the SSPX in France); Father Grégoire Celier (SSPX priest, author and philosopher); Father Arnaud Rostand (head of communications for the SSPX General House at Menzingen in Switzerland and former district superior of the USA), Father X (a senior cleric in a major SSPX district who spoke on condition of anonymity) and Ennemond, a leading traditionalist blogger and SSPX insider.

The second aim of the article is to reanalyse the SSPX's political discourses and reconceptualise its links with Lefebvre's biography. This analysis will be based first on the official communications of Fr Régis de Cacqueray (the SSPX's superior in France, 2000-2014), and those of Bishop Bernard Fellay (the SSPX's general superior during the same period), and, second, on a comparison of Lefebvre's activities before and after the founding of his congregation. The urgency of the current moment renders the words and options of these recent leaders far more pertinent 
than the intégriste overtones of passing remarks made by Lefebvre or any of his priests.

In conclusion, this article will address the implications of the SSPX's potential reconciliation with mainstream Catholicism under Pope Francis whose papacy is sure to mark the Catholic Church in as yet unanticipated ways. Paradoxically, it may take the suppleness of the liberal Pope Francis to achieve the reconciliation with the intégristes longed for by Francis's rather more dogmatic predecessor Benedict.

\section{Part 1}

The overwhelming claim of the existing historiography is that Lefebvre's own biography and his views on certain events in French political history offer the key to the nature of the SSPX. This of course raises several problems, and not least the matter of how well established are the causal connections between Lefebvre's life and the character of the movement he founded, between l'homme et l'oeuvre, as it were. In recent studies Florian Michel's essay (2009) provides the most concentrated example of this historiographical trend that stretches from Congar (1977) and Poulat (1985) to Rémond (1989) and Fouilloux (1997). Thus, Michel's discussion of the SSPX's franco-catholicisme will serve as a useful test of the scholarship on the question in this first part of the article.

In his chapter Michel (2009) deploys four lines of argument to demonstrate the filiation of the Lefebvrists to Action française, and by implication to the wider family of the French far right. Nevertheless, at least one of his arguments - that Lefebvre and the SSPX are quasi-Gallicans because their critique of the pope 
depends on the possibility of distinguishing the person of the pontiff (sedens) from his office (sedes) - can be dismissed without further ado. That the pope can err is a long established principle not in contradiction with Pius IX's bull Pastor Aeternus defining papal infallibility. Cardinal Robert Bellarmine, the greatest theologian of the early modern period and a canonized Doctor of the Church, wrote in De Romano pontifice (1588) about what the Church should do were the pope ever to fall into heresy. All that said, Michel puts forward three other arguments about Lefebvre and the SSPX that all merit much closer scrutiny.

The first concerns the impact of Lefebvre's training at the Séminaire français in Rome the mid-1920s. There, he came under the influence of the rector Fr Henri Le Floch who, following the papal condemnation of Charles Maurras's Action française, was sacked in 1927 for his pro-Maurrassian sympathies. After his dismissal Lefebvre's father wrote a supportive letter to Le Floch, mentioning the great debt Marcel owed the former rector (Prévotat, 2009). Later on in 1947 at the dinner celebrating his episcopal ordination, Lefebvre toasted the name of Fr Le Floch, much to the horror of Cardinal Liénart (Lefebvre, 1999: 61). In Michel's logic (2009: 38), this evidence proves an attachment that illuminates Lefebvre's habit of dissidence: such are the children of Action française. Is it any wonder, Michel implies, that such an admirer of Le Floch ended up as a notorious critic of the official Church? Lefebvre and his movement are thus seen as indubitably Maurrasssian.

There is a good deal of confusion here, however. Yves Congar enunciates the complexity of the question, hinting that Lefebvre was seen as 'un homme de droite accordé aux positions de l'ancienne Action française', while later describing him as 'trop homme d'Eglise, maître de soi, au surplus, amiable pour être à ce point 
politique et sectaire' (1977: 13 and 15). In this light Michel is frankly too eager a counsel for the prosecution. He quotes Lefebvre's claim, made in the 1970s, that he had never read a line of Maurras, but then refers triumphantly to Lefebvre's 1987 publication Ils l'ont découronné (1987) where the archbishop quotes Maurras several times; as if the first claim did not predate this evidence by ten years. Even then, in I/s l'ont découronné Lefebvre frequently uses Maurras simply in relation to discussions of Thomistic or Aristotelian political theory, rather than with regard to more distinctly Maurrassian theses based on the logic of politique d'abord. That Maurras was part of Lefebvre's mental universe is, therefore, unquestionable; that he is, consequently, a vital influence on Lefebvre and the SSPX is much less certain.

Since this is the most substantial of Michel's arguments, the evidence supporting it deserves further consideration before we move on. Action française's newspapers have long been sold outside some SSPX churches or gatherings, especially in Paris. Lefebvre's devotion to the figure of Maréchal Pétain did not diminish after the fall of Vichy France. Late in life Lefebvre was found guilty by a court of having made racist remarks after stating at a press conference his fears for the impact of Muslim immigration in France. ${ }^{1}$ On the question of the SSPX's association with the wider far right, Fr Paul Aulagnier, then SSPX superior in France, celebrated a mass for Le Pen supporters during the FN's breakthrough year of 1984 (Chombart de Lauwe, 1991); it is presumably on the basis of this apparently one-off event that Roberts (2000: 273) makes the claim that 'annual Front National party celebration is preceded by a Latin Mass'. Last of all, even the current SSPX French superior Fr Christian Bouchacourt (2015) admits that a regular Requiem Mass for 
those massacred in the Rue d'Isly in 1962 - a pieds-noirs cause célèbre - is held regularly at St Nicolas du Chardonnet, the Lefebvrists' principal church in Paris. All these factors considered, therefore, it would be unfair just to dismiss Michel's claim of Maurrassian or far-right leanings in the SSPX.

Nevertheless, voices from within the SSPX contest the hard-right filiation such evidence would point to. Fr Arnaud Rostand (2015) argues that Lefebvre's interest in figures such as Maurras or Pétain arose because of their occasional defence of principles of Catholic social or political doctrine. While hopelessly reductionist, Lefebvre's remarks on Muslims in 1989 were based less on native French racism and more on the bitter tensions he lived with in Senegal in the 1950s where, much as in parts of today's Middle East, slavery and the persecution of Christian converts were features of daily experience (Tissier de Mallerais, 2002: 255). Lastly, according to Priest X (2015), while Bouchacourt's predecessor, Régis de Caqueray, got the SSPX increasingly involved in public protests that verged on political events (Colard and Moulène, 2011), many of the SSPX priests in France were unhappy with the prospect of ordinary lay folk being unwittingly manipulated by political forces (Priest X, 2015). This last picture of internal SSPX tension over political engagements departs from the customarily undifferentiated depictions that we find in accounts of the movement in France. To sum up, while it is impossible to assess the proportion of Maurrassian sympathisers among SSPX supporters whether globally or just in France, nevertheless, the conclusion that Lefebvre and his congregation are common or garden Maurrassians is simply caricature. 
Michel's second line of argument about the SSPX concerns the personal or familial connections between Action française and the Lefebvrists. One notable example is Bernard Tissier de Mallerais, the most senior of Lefebvre's bishops and also his biographer. Charles Maurras was a witness at the marriage of Tissier de Mallerais' grandfather and the family stayed loyal to Action française. Other Maurrassian figures in Lefebvre's life, according to Michel, include far-right intellectual Jean Madiran, a Lefebvre loyalist until 1988, and the theologian Fr Victor Berto, a close friend of Lefebvre and a lifelong admirer of Maurras. It is worth noting that Régis de Caqueray's family were likewise from Maurrassian circles (Priest X, 2015). De Caqueray, as mentioned above, encouraged the noisy activism of the Institut Civitas who see themselves as the heirs of Jean Ousset's Cité catholique, an organisation supported by Lefebvre in the 1960s (Senèze, 2012).

Once again, however, the evidence assembled here is suggestive, rather than conclusive; a case of guilt by association. There is nothing intrinsically political in a Maurrassian like Madiran sympathising with Lefebvre for what were theological motives; dissatisfaction with Catholicism's modernisation stretched right across French society, from Georges Brassens to Jean Fourastié. Furthermore, Poulat's claim (1985) that the larger proportion of the Lefebvrists actually come from Maurras's movement has little hard empirical evidence to underpin it. That Maurrassians have flourished in the movement is clear. That they have caused considerable unhappiness in the movement (Priest X, 2015) is less known. That Poulat's accusation arises from a conflation of Maurrassianism and certain forms of pre-conciliar theology is all the more likely since, curiously, the burdens of Maurrassianism have long been skewed in the perception of many French people. 
Students of Lefebvre at the Holy Ghost Fathers' seminary of Mortain in 1946 later remembered his reading from 'un livre d'Action française', whereas the book in question was actually La Révolution française, à propos d'un centenaire by the bishop of Angers, Mgr Freppel, written in 1889 (Tissier de Mallerais, 2002: 159). The final argument that Michel posits to align Lefebvre and the SSPX with Action française and the French far right concerns Lefebvre's attachment to Rome. Lefebvre maintained an elevated notion of romanità, another sign of his debt to the ultramontane Fr Le Floch. He wanted his own priests to share this Roman passion, to which end he bought a house at Albano near Castel Gandolfo where his clergy could absorb the spirit of the Eternal City (Tissier de Mallerais, 2002: 479-80). For Michel, this factor completes a puzzle that points unerringly towards a Maurras-Lefebvre, far-right convergence.

Prima facie, this argument has more weight to it. Lefebvre's romanità smacks of the artificiality of the romanità of Maurras and Action française, an unconscious construction more revealing of those who embraced it than of the city or civilisation it denoted attachment to (Sudlow, 2011). Nevertheless, Michel's evidence here is again oddly chosen. He finds this romanità best epitomised by Victor Berto, Lefebvre's friend and theological adviser but Berto was dead two years before Lefebvre's SSPX was even founded. Moreover, if Lefebvre's romanità was so wayward, it would be a huge paradox not only that he was chosen as a bishop but also that he became the papal delegate for West Africa. On the other hand, were one to concede the waywardness of Lefebvre's romanità - for clearly something went deeply wrong in his relationship with Rome - one might more realistically 
ascribe it to his long absences in Africa, far away from Rome and its intellectual and theological climate, rather than to the purported influence of Maurras's romanità.

To sum up, this article takes direct issue with the historiographical trend that Michel exemplifies. The latter's lines of argument are suggestive rather than wholly persuasive (e.g. Lefebvre's training under Le Floch); its evidence is circumstantial rather than substantial (e.g. the family connections with Action française); its observations seem frequently to lend enormous weight to the incidental rather than then essential (e.g. the supposed role of Victor Berto). This is not to say that it is simply and wholly wrong about the Lefebvrists. Its argument, however, seems to be beset by reductionism and critical franco-centricty.

Evidence of the reductionism is found in the tendency to exaggerate the importance of Lefebvre's occasional brushes with Action française and its torchbearers, his affection for Pétain or the presence of hard-right voters at his chapels. Indeed, evidence of the inaccuracy of this reductionism has been around for years. Against expectations, in the mid-1980s Henri Tincq found traditionalists just as likely to be voting RPR or UDF (Le Monde, 7 March 1986). Moreover, to say extreme elements prove the extremism of the SSPX is just as simplistic as saying that a militant tendency in the British Labour Party makes the party extreme, or that all Muslims sympathise with violent Jihad. Again, estimating how many far-right extremists are present among SSPX supporters is very difficult. Quite simply, the porous borders of SSPX support, its developing relationship with the Rome of Pope Francis and the shifting terrain of the French far right render this an exercise fraught with many unquantifiable factors. 
What compounds the reductionism noted above is that some historians seem to assume there is no such thing as a religious motive; or that all religious motives are political agendas with theological pretexts. In the case of someone like Lefebvre whose intellectual sources were overwhelmingly theological - a fact easily borne out by the footnotes and bibliographies of his four principal works $(1976 ; 1985 ; 1987$; 1989) - this is an egregious mistake. Crucially, Lefebvre spoke far more often about the principles of Catholic political theology, notably his preoccupation with the Catholic state (Lefebvre, 1987), than about the circumstances of political history. In this light, his occasional sallies into political commentary - for example, his praise in a sermon in 1976 for the regime of General Videla in Argentina (Tissier de Mallerais, 2002: 517) - reveal more a clumsy and unworldly naivety, blind to certain political realities, rather than politically extremist engagement. In fact, if we follow Lefebvre's logic to the bitter end, the conclusion might be otherwise: that when he and the SSPX have proffered political commentary as an application of theological conviction, they have often thoughtlessly inflicted on themselves a case of 'collateral baggage'. By collateral baggage we mean the ideological and partisan burdens resulting from political or historical dialectics that get attached to positions that are properly theological or philosophical. Contemporary historians easily and rightly accept that not all Muslims are Jihadists. They might just as easily accept that not all Lefebvrists are Maurrassians.

The second reason for arguing that the historiography about the Lefebvrists is unsatisfactory is because it tries to explain Lefebvre and the SSPX in the rather narrow frame of his French origins and experiences. Michel and Levillain admit the role of other nationalities in the SSPX, but the latters' place in the resulting analyses 
remains minimal. Paradoxically, while many historians like to theorize Lefebvre's options from a franco-centric perspective, it is their own start and end points that remain largely franco-centric. Proof of this franco-centricity lies in the theorizations linking Lefebvre's biography to the character of the SSPX that consistently omit Lefebvre's thirty years in Africa where he served principally in Gabon and Senegal. If Lefebvre had died in the 1960s, he would be remembered as a major figure in the development of West African Catholicism, a fact that bewilderingly many historians have overlooked.

To point out the limitations of this historiography is not to sanitize the movement or the man; it is obvious why large sections of the contemporary French Church would quail at the prospect of reconciliation with this group. Nevertheless, the critical consensus represented by Michel seems partial and selective. To understand the politics of the SSPX we need a closer examination of what exactly the leaders of the SSPX say. To grasp the relation of Lefebvre's life to his congregation, we need an account of Lefebvre's life that does not exclude arguably its most significant portion: his thirty-year ministry in Africa. It is to such analyses that this article now turns.

\section{Part 2}

In order to counter the two historiographical weaknesses of reductionism and franco-centricity, the second part of this article will address three questions.

First, by way of testing the real political views of the SSPX, we will consider how politico-theological theses have been advanced recently by the SSPX leadership in France, weighing up whether they should be seen as far-right political 
theorizations or else as a form of political theology. This analysis will be based on a corpus of texts by Fr Régis de Cacqueray, French superior for the SSPX until 2014, beginning in 2005 with a keynote interview with the far-right review Présent. Totalling 23,987 words, these texts include his Letter to Friends and Benefactors (2010-2014), and a range of other statements, letters and sermons published on the SSPX's French website, La Porte Latine. ${ }^{2}$ The preoccupations that emerge from this analysis will then be compared with the concerns of the international Letters to Friends and Benefactors of the SSPX written by Bishop Bernard Fellay, the current Superior General of the congregation (15 letters from 2005-present, containing 34,105 words). Rooted in an understanding of thematic intertextuality recently observed in other political discourses (Austermuehl, 2014: 38), the aim of this comparison is to establish what specific difference the French district offers when compared to the international body of the SSPX, at least at the level of official discourses on political matters broadly defined. The shorter corpus of the French superior is justified on the basis that De Cacqueray is perceived as having been the most politicised holder of the office of French superior (Priest X, 2015). The empirical basis of this analysis and juxtaposition of French and international questions should offer a way out of reductionist interpretations and provide a more reliable account of the political contours of the SSPX than can be found in loose associations and circumstantial allusions.

The second task of this section of the article will be to break with the francocentric interpretation of Lefebvre's biography to offer an analysis that establishes the importance of Lefebvre's African missionary experience to the way in which the SSPX has evolved. Lefebvre's missionary activities in Africa and in the SSPX saw him 
erect or develop communities that can be seen as social learning systems. Primarily, a social learning system (Wenger, 2000) is a means by which knowledge is acquired through the shared contexts and practices of some organisation or community. More importantly, it is a system in which identity and unity are affirmed through a complex convergence of practices and perspectives. The argument here will be that Lefebvre's practices of evangelization (that were not of course exclusively his) contributed to a holistic formation not only in Christian values and practices but also in a Christian weltanschauung. What most historians of the SSPX seem to have missed is that the ten years separating Lefebvre's return from Africa and his founding of the SSPX are a comparably short hiatus in nearly sixty years of continuous practical missionary activity in Africa and across the globe. Indeed, since for five of those ten years he was superior general of the Holy Ghost Fathers, an international missionary congregation, we could reduce the hiatus to five years. We will better establish this hypothesis of the contiguity of Lefebvre's African and SSPX phases by identifying the key practices Lefebvre deployed in Africa and then by correlating these with the development of the SSPX. This approach should provide a response to the franco-centric nature of the analyses hitherto considered.

Finally, in the light of the answers to these two inquiries, the article will address the current state of the SSPX under the papacy of Francis, a pope whose politico-religious options have surprised many.

An initial examination of the corpus of erstwhile French SSPX superior Fr De Cacqueray suggests his political engagements lie between religious tokenism and 
illiberal protest. His 2005 interview with Présent illustrates this abundantly. Therein, for example, he denounces the suppression of Pentecost Monday as a jour férié, even though no Catholic is required to go to church on this day. He likewise praises the work of the Collectif contre I'homofolie, a Belgian movement that opposed early moves for gay marriage; in this sense De Cacqueray's anxieties preceded by a few years the politically varied constituency that eventually coalesced in the manif pour tous. To these themes De Cacqueray adds the cause of the pro-life movement who must aim to 'expier le massacre des enfants innocents' authorised by the Loi Veil (De Cacqueray, 2005). Here again, even if the language is hard hitting, the issue is hardly an exclusive concern of the far right.

De Cacqueray is most often associated with the Civitas Institute, although this body does not figure at all in the corpus and is notably absent from his Letters to Friends and Benefactors (2010-2014). In fact, when he addressed the Civitas colloquium in 2014, the principles that he evoked were an agenda for moral politics, rather than a far-right manifesto (Dickès, 2014). Civitas itself has links to far-right movements, notably Action française, Carl Lang's Parti de la France and Renouveau français. Yet, when reporting on the 2015 Jeanne d'Arc March in Paris, Libération itself observed that the politicking and slogans of such groups were at a strange remove from the rosaries being quietly muttered by some following the same procession (Sauvaget, 2015). According to well-known traditionalist blogger and SSPX insider Ennemond, this was one of the problems (also identified by Priest X) that began to drive a wedge between the SSPX in France and the Civitas Institute: it was not always clear when a religious 'procession' might turn into a political 'manifestation' (Ennemond, 2015). 
If such examples reinforce the existing characterisation of the SSPX as part of the far-right family, we must take account of the grounds on which De Cacqueray advocated political activism. Behind his various engagements stands a tangible political theology that draws on well-known, pre-conciliar sources. De Cacqueray, for example, references St Augustine's treatise De Civitate Dei, concerning the tensions between the City of God and the City of Man, the latter conforming to an anthropocentric vision of human life impermeable to the divine. Crucially, this distinction of the two cities envisages for De Cacqueray a hierarchical resolution to the relations between Church and the secular State, markedly different from the largely cooperative and egalitarian strategy envisaged by Gaudium et Spes (1965), the Second Vatican Council's charter for relations between the Church and the modern world.

Following Lefebvre's lead, however, De Cacqueray's contemporary politicotheological reference (2005) is the encyclical letter Quas Primas (1925) of Pope Pius XI concerning what political theology used to call the social reign (or kingship) of Christ. Pius XI taught the necessity and beneficial effect of the public marriage of Christian doctrine with legal, judicial and social structures appropriate for the postmonarchical age. Oddly enough, reductions of Lefebvre's political attitudes to those of the Maurrassian family never mention Lefebvre's far more profound and explicit attachment to Quas Primas, the work of the very pope who condemned Maurras's movement.

The practical implications of such theological reference points are not party political so much as theologo-hierarchic. De Cacqueray denies he is a practitioner of clericalism, but in his interview with Présent his defence of the indirect power of the 
clergy over the political action of the faithful smacks powerfully of Gambetta's apodictic enemy. In this sense De Cacqueray's agenda cannot properly be aligned with any contemporary far-right movement or party, nor even with the tradition of Action française, but should be seen as a throwback to the movement of Catholic political action initiated by Popes Leo XIII (1891) and Pius X (1905) wherein the Catholic laity were enjoined to promote Catholic values and principles in the political domain. De Cacqueray himself could easily have written the following lines which come from an encyclical of Pope Pius X. According to the patron of the Lefebvrists, every Catholic must act

[accept and fulfil] public offices with the firm and constant resolution of promoting by every means the social and economic welfare of the country and particularly of the people, according to the maxims of a truly Christian civilization, and at the same time defending the supreme interests of the Church, which are those of religion and justice (Pius X, 1905).

Insofar as De Cacqueray has a political agenda corresponding to this political theology, it thus amounts to the instrumentalisation of potential political partners and the actualisation of the laity's subsidiarity in the temporal order, in pursuit of the realisation of values identified in the concept of the social kingship of Christ. IIs l'ont découronné, as the title of Lefebvre's book suggests (1987), is principally a lament about the deconstruction of this theological model of the social order, rather than about French royalist nostalgia.

This subsidiarity of the laity applies also to political leaders whose conversion to the Catholic faith would, De Cacqueray believes, inexorably determine the fate of Catholics and of others around the world. Such is De Cacqueray's argument (2010) in 
response to Islamist attacks on Catholic churches in Iraq in 2010. Yet this last example also illustrates De Cacqueray's tendency to confuse the categories of religious imperative (conversion) and political sociology (the social effects of such conversion). De Cacqueray's use of these attacks on Iraqi Catholics is particularly incoherent, not least because he declares them to be martyrs while at other times bemoaning the kind of Catholicism that they espouse (De Cacqueray, 2013a).

It is also in this theological frame that De Cacqueray's views on Islam can best be inscribed. In the corpus of his writings and addresses, he mentions 'islam' only three times and 'musulmans' six times, yet only in one instance does this concern the customary far-right anxiety of the growth of Muslim numbers in former Christian nations (De Cacqueray, 2010). In all other instances De Cacqueray attacks contemporary Catholic attitudes to Islam that he considers theologically relativist or at least irenicist. His model is St Francis of Assisi who, he argues, met with Sultan Al Malik Al Kamil only to convert him to Christ (De Cacqueray, 2013b). The term 'croisade' only occurs twice in De Cacqueray's corpus; once in relation to a recruitment drive for vocations to the priesthood, and once in relation to the campaign of prayers organised by Bishop Fellay for the sake of reunion with Rome. In neither case, therefore, does such language refer to a politically conflictual relationship to Islam itself.

All this evidence points to the conclusion that under De Cacqueray (superior from 2000-2014) the SSPX in France was offering not a religious version of the far right but an attempt at a soft clerical dirigisme, aimed at encouraging at worst the spread of an admixture of traditional Catholic values and conservative authoritarianism. This dirigisme is soft because none of the 'political' injunctions 
above are enforced by any kind of ecclesiastical discipline. That the partners De Cacqueray would choose to instrumentalise are mostly members of the far-right family is yet further proof of the SSPX's unconscious proclivity for 'collateral baggage'. Of course it is their own fault if the formal theological motives for approaching the political domain in this way are simply ignored or assumed to be window dressing for covert extremism.

Such conclusions are corroborated when we look at the international context of the SSPX under Bishop Fellay, the superior general of the congregation since 1994. An analysis using AntConc software shows that religious or theological terms in Fellay's Letters to Friends and Benefactors (e.g. Dieu, Eglise, Messe, Seigneur, Jésus, etc.) are three to four time more frequent than terms that denote more ideological preoccupations (e.g. liberté, Révolution, libéralisme). Whatever entanglements individuals might contract at ground level, the institutional SSPX remains focused on the theological.

As with De Cacqueray, Fellay's letters contain only a few references to France or French current affairs. His December 2011 letter criticises the failure of Catholics to protest against blasphemous theatrical performances in Paris; again, the concern is primarily a religious one, and while it can be seen as an illiberal position, it is an engagement broadly in step with Catholic sensibilities, rather than with any political coloration. A further reference to France in Fellay's December 2013 letter quotes Lefebvre's call for Catholics to work for the conversion of the nation. Here again, there is nothing particularly unusual about a Catholic organization dwelling on its commitment to evangelisation, regardless of the apparent hopelessness of such a cause in the current sociological conditions of unbelief. The last reference to France 
in Fellay's corpus comes in a letter of April 2014, again quoting Lefebvre in associating the French and the Russian Revolutions. While such an association results from a schematization of political modernity, what drives it are religious markers that have been well established on theological grounds. Indeed, for Fellay following Lefebvre once more - Pope Pius XI is a lodestar not only for his teaching on the social reign of Christ, but also for his opposition to communism (Divini redemptoris, 1937), and his strict teaching on ecumenical relations (Mortalium animos, 1928). Crucially, when the term 'Etat' is used, both in Fellay's letters and De Cacqueray's texts, it is in almost all circumstances associated with a discussion of the theory of the 'Etat catholique' and the ideal of a society that publically acknowledges the Catholic faith as its prime cultural value.

To sum up our answer to the first part of this section, a close examination of the official interventions of the recent SSPX leadership in France, and on the international stage, at least since the year 2000, make it much harder to sustain the far-right characterisation that the existing historiography has lent to the SSPX. The SSPX's political discourses, at least since 2000 , are better explained as an attempt to realise an indirect clerical dirigisme over the laity as a tactic to encourage the wider strategy of the social reign of Christ, rather than as a sign of its political affiliation. The SSPX stands much more for the social kingship of Christ than it does for the political prospects of the French far right. Once again, this is not to wholly dismiss the evidence assembled by previous historians on the question of the SSPX; the recent notoriety of the now expelled Bishop Richard Williamson is evidence enough that the SSPX has at least been a haven for some extreme political views. Nevertheless, De Cacqueray's and Fellay's writings show that the loose associations 
historians have emphasized between the Lefebvrists and Maurrassians are now better classed as peripheral than as essential factors in the construction of the SSPX's identity.

Moving now to the connection between Lefebvre's life and the character of his congregation, the aim here is to eschew the franco-centric perspective adopted by others and replace it with a richer account of Lefebvre's biographical trajectory and its impact on the SSPX. As we noted above, Lefebvre's political sympathies or brushes with far-right movements throughout his life are believed by many to provide the key to exposing the real character of the religious congregation he founded. The gap in this analysis, as we have noted, is that Lefebvre spent most of his life until he was 65 as a missionary in Africa, well away from French current affairs but wholly invested in spreading Catholicism throughout Gabon and Senegal. Indeed, after his departure from Africa, his memory remained keenly alive in Gabon where a commemorative set of stamps was issued in 1996 five years after his death. For reasons of space we can only suggest here an outline of how Lefebvre's African experiences illuminate his subsequent work with the SSPX across the globe. To undertake this analysis, elements of Etienne Wenger's social learning system theory (2000) will be used to elucidate the parallel strategies of belonging that Lefebvre practised in Africa as a missionary and later encouraged within traditionalist circles. These strategies are three in number: engagement, by which Wenger means common practices that shape the subject's view of the world; imagination, by which Wenger refers not to fantasy but to the kinds of imaginative 
communality identified by Benedict Anderson (1983); and, alignment, by which Wenger envisages the harmonization of local practice with that of the wider community.

Now, a broad sweep of Lefebvre's missionary activities and his development of the SSPX reveals that all three forms of belonging appear to be strongly characteristic of his agendas in Africa and across the globe. The source of the data that follows concerning Lefebvre's missionary activities and the SSPX's own development is Tissier de Mallerais's biography (2002). While shot through with ideological bias, the biography is widely accepted as an extensive documentary work whose exploration of pertinent primary sources was only hindered by the refusal of some Catholic institutions to allow Tissier de Mallerais's research team access to their records.

The first of Wenger's modes of belonging that characterises Lefebvre's missionary activities is that of engagement. By engagement Wenger refers to 'doing things together [...] The way in which we engage with each other and with the world profoundly shape our experience of who we are'. (Wenger: 2000, 227). In Africa such agendas were tangible in the many missions Lefebvre built or managed between 1929 and 1961. Later he would tell his seminarians at Econe, 'Regrouper les gens autour de l'autel: tel est le but du prêtre. Aussi, en mission, la première chose à faire dans le secteur, c'est bâtir une église' (Quoted in Tissier de Mallerais, 2002: 135). Yet for Lefebvre, schools were also central to this process. As a newly ordained bishop in Dakar he established the college of Sainte Marie de Hann for boys in 1947 (there were already four schools for girls) and commissioned religious congregations other than the Holy Ghost Fathers to teach in the diocese. None of this could have been 
accomplished without the benefactor network that Lefebvre constructed during a tour of France in February 1948 (Tissier de Mallerais, 2002: 179). For Lefebvre, engagement was thus a reciprocal intercontinental practice, stretching from the construction of missions in Africa to support of the missions by wealthier Catholics back in Europe.

Significantly, the way in which the SSPX has developed its missions reflects exactly the same agenda, although the SSPX schools and parishes act as alternatives to the mainstream parishes and schools which the traditionalist faithful flee. Before the Council the Swiss theologian Hans Urs von Balthasar had called for a razing of the bastions of Tridentine Catholicism. If anything Lefebvre was aiming to build them up again. The SSPX priory was meant to function as an 'apostolat de diaspora' from which the priests would travel out to distant missions 'comme en brousse' (Tissier de Mallerais: 2002, 539). From the 1970s the SSPX supported the traditionalist schools of Fanjeaux and Brignoles run by Dominican sisters. Many secondary and primary school foundations followed across France and then the rest of the world. In 2015 the SSPX could count 175 priories globally, served by 590 priests, while in France the figures are proportionally impressive: 150 priests scattered across thirty-six priories, thirty primary schools, twelve secondary schools, a university institute and a seminary. ${ }^{3}$ If doing is believing, Lefebvre's missionary activities, especially in education, were clearly meant to engage the faithful in practical ways that help engender belief. From this perspective Lefebvre's African engagements and the SSPX's were in strong sociological continuity, even if the latter's were canonically irregular. 
In Wenger's schema, imagination is a second feature of social learning systems, intensifying the sense of belonging facilitated by engagement. Wenger's understanding of imagination (2000) echoes that of Benedict Anderson. In fact imagination's contribution to belonging echoes in the psychological sphere the work done by common practices of engagement in the material sphere.

Now, in Lefebvre's African missions the psychological parallel to schools and parishes was provided by the contemplative orders. Lefebvre had a predilection for the Carmelites and the Benedictines whose vocations were those of prayer and liturgy, prime sources of the Catholic imagination (Greeley, 2001). When the Carmelite sisters arrived in Dakar in 1951, Lefebvre presided over the ceremony of 'enclosure'. Later, he deferred the refurbishment of his residence to fund the construction of a new building for them (Tissier de Mallerais: 2002, p. 192). In addition to being influenced by Dom Chautard's L'Ame de tout apostolat (1912), a widely read work that placed the contemplative life at the heart of the Church's missionary activity, Lefebvre belonged to that generation who absorbed St Therese of Lisieux's writings on the unity of the contemplative and missionary dimensions of the Church. This active-contemplative paradox is embedded in the Catholic view of evangelization in the early-to-mid twentieth century. Crucially, two years before Lefebvre went out to Africa, Pius XI (1927) declared St Therese (a nun from an enclosed Carmelite convent in Normandy) 'patroness of the missions'.

Lefebvre's commitment to contemplative life - and to encouraging the Catholic imaginative worldview that it facilitates - has been recapitulated strongly in the SSPX. The SSPX even has its own contemplative wing of religious sisters who live a rule of dedicated silence and prayer. The SSPX has likewise supported the 
foundation of other traditionalist versions of religious orders, otherwise reformed under the aegis of the Second Vatican Council. These include Benedictine monasteries at Bellaigue, Silver City (USA) and Le Barroux (now reconciled with Rome) and Carmelite convents at Quiévrain in Belgium and Spokane in the USA. The traditionalist Dominican fathers at Avrillé near Angers lost some members to Rome in 1988, while the rest have recently aligned themselves with Bishop Richard Williamson, one of Lefebvre's four bishops who was expelled from the SSPX in 2012 for constant insubordination and holocaust revisionism. This kind of imaginative belonging under the Lefebvrist umbrella is another proof that the SSPX are not simply the religious inflection of a political view. If refreshing the deep imaginative sources of contemplative life represented one of Lefebvre's keenest ambitions while in Africa, it remained so in the development of his own traditionalist congregation after the Council.

The last function of social learning systems classified by Wenger (2000) is alignment. This requires the calibration of individual actions with those of the wider group to which one belong. It involves, moreover, a coordinating of perspectives, interpretations and actions, all of which fuse in the identity that any social learning system enshrines. In other words, alignment completes the social learning to which engagement and imagination have offered the initial coordinates.

If there is one dimension of Lefebvre's work that corresponds to this process, it is surely his training of priests. From early on in his career, he was involved in forming the clergy, contributing significantly to a Church policy that developed the indigenous clergy of the African continent (Tissier de Mallerais, 2002: 112 and 243). By 1934 he was the rector of the seminary in Libreville with nearly 50 students under 
his guidance. He was a talented director of seminarians, such that the Holy Ghost Fathers drafted him back to France in 1945 to take over their philosophy scholasticate at Mortain in Normandy. While Wenger disassociates authority from the process of alignment, it is clear that the kind of alignment required by a Catholic worldview demands the constant readjustment that can only be provided by authoritative guides.

In essence, the training of priests was what the SSPX was established to do when it was founded: such were Lefebvre's stated aims in the constitutions (Tissier de Mallerais: 2002, p. 437). Moreover, Lefebvre had no ordinary ideal of the priesthood, evincing an almost Bernanosian passion for the sacerdotal vocation. For him, it was theologically and strategically at the heart of Catholicism's fight with modernity and the decline of faith. In one of his last works, Itinéraire spirituel, he describes being haunted by the desire to 'désigner les voies de la vraie sanctification du prêtre' (Lefebvre: 1989). Thus, through the 1970s and 1980s the SSPX would open six seminaries: in France, Switzerland, Germany, the USA, Australia and Argentina. Lefebvre placed the SSPX under the patronage of the Pauline inspired title of 'Christ, the High Priest'. As an agent of alignment the priest in Lefebvre's eyes is clearly the alter Christus. The priest's training in alignment with the Church is quite simply a propaedeutic of the alignment with Christ that the priest facilitates in the faithful.

Analysing Lefebvre missionary practices and the development of the SSPX in the light of Wenger's social learning system shows the degree to which the evolution of the SSPX after the Council was deeply embedded in Lefebvre's missionary experience. So much of what now characterises the SSPX in France and on the 
international stage relates directly to these practices of engagement, imagination and alignment, much more than to the supposed importance of Lefebvre's occasional associations or supporters.

In this light, moreover, and far from the franco-obsessive nature of some historical judgments on the matter, Lefebvre and his congregation could be much better defined as quasi-nationless missionaries, bent on both individual and societal evangelization, more than on French political engagement. If Lefebvre was of course engaged strategically and diplomatically with the French authorities while in Africa, and in this sense might be seen as one of the ecclesiastical dignitaries who acted wittingly or unwittingly as vectors of French cultural and political influence (White and Daughton, 2012), this was hardly a role he continued in after his departure from the continent. Indeed, it is surely the quasi-nationless character of the SSPX that explains why they have prospered so well in so many different countries. In this context, the temptation to pin the character of the SSPX on Lefebvre's francité does not even come close to exposing these deeper and arguably far more influential factors in Lefebvre's life.

There is a clear parallel here with the franco-centric analyses of the SSPX's political tendencies. Just as an analysis of the SSPX's political theology provides a clearer grasp of what they stand for than can be gleaned from incidental political friendships, so an analysis of Lefebvre's life that embraces his African experience provides a better understanding of the roots of the SSPX. Of course we cannot discount the formative power of the very real disagreements that the SSPX have had with Rome and which have not been the focus of this study. Neither, as we have said, would it be wise just to dismiss the fact that even if the SSPX is not the acolyte 
of the FN or the heir of Maurras, extremists such as Richard Williamson have dwelt within it with some ease. Nevertheless, narrow accounts of Lefebvre's life and its influence on the SSPX will no longer do. In the medium to long term, a better understanding of the relationship between all these phenomena will help make sense of what looks like the coming reconciliation of the Lefebvrists, at least if Pope Francis has anything to do with it.

\section{Concluding remarks}

In his book preceding the conclave that elected Benedict XVI, John Allen (2002), perhaps the leading English-speaking Vatican specialist, distinguished three broad tendencies within the Sacred College of Cardinals that are reflected throughout the worldwide Church. The first was the 'border patrol' tendency, comprising those cardinals most attentive to the contours of Catholic dogma and determined to preserve Catholic identity in the face of relativism and secularization. There was also the 'salt of the earth' tendency whose emphasis was less on dogmatic purity and more on the Church's engagement with the world, especially in matters of social justice. Finally, there was the 'reform' tendency who were looking for greater devolution of power from Rome to the national churches and for a revival of the spirit of Vatican II (Allen, 2002: 138-152).

Being of the 'border patrol' tendency has been both the SSPX's strength and Achilles heel. It has been their strength since, for example, their dogged defence of the traditional rites has in a sense won out. Some have even argued that without Lefebvre's defence of the traditional rites, there would be no approved traditionalist movement, and no official recognition of the pre-conciliar liturgy. It has also been 
their weakness, however, since it is precisely their wariness over doctrinal purity that has prevented them signing up to a series of potential agreements with Rome, most recently in 2012. If for once, however, the SSPX could adopt a more 'salt of the earth' approach to relations within the Church, they might find certain conditions most auspicious.

For example, as mentioned above, Pope Francis has conferred canonical jurisdiction on them for the Year of Mercy, 2015-16. It is very probable, however, that this jurisdiction will remain in place beyond the end of 2016 since it would require a potentially damaging process to withdraw it thereafter and the reopening of old wounds. Moreover, this move lifts a taboo on the SSPX that has kept some conservative Catholics from openly participating in the sacraments in their churches. In France another notable factor affecting the appeal of the SSPX is that since the manif pour tous many of the younger traditionalists have become less partisan about where they attend the traditional liturgy. According to Ennemond (2015) and Priest X (2015), these young traditionalists are much readier for a policy of coalition than the generation before them who were scarred by the rupture in 1988. A third important factor again goes back to Pope Francis and it is the fact that his noted openness towards a latitudinarian Catholicism - exemplified in his readiness to contemplate allowing the divorced and remarried to receive the Eucharist - has discredited him in the eyes of even moderate Catholic conservatives more accustomed to the steady doctrinal hand of Benedict XVI and John Paul II. An ever-larger conservative caucus within Catholicism, strengthened by a softer traditionalism and a harder conservatism, is a growing possibility. Time will tell. 
There are, nevertheless, other factors that could militate against a welcoming back to the fold of the SSPX, especially in France. First, while recent trends in French Catholicism suggest to some (Bastié, 2015) the growth of a 'révolution silencieuse' among 'catholiques d'identité', notably since the manif pour tous, there is no guarantee that this constituency will simply embrace the intégristes after so many years of separation and with all the latter's collateral baggage. Second, the political decontamination of the SSPX is far from assured, even under the leadership of the relatively moderate Swiss Bishop Fellay. Those priests of the SSPX who continue to hit the headlines in France, most recently Fr Xavier Beauvais (Le Figaro, 2015), tend to be from its extremist tendency. Lastly, since the rest of the church in France is unlikely to return to a celebration of the traditional rites - in spite of the fact that $20 \%$ of France's new priests are now celebrating those rites - it is far from certain that the traditionalists' most emblematic stances will be integrated into the united front that French Catholicism must offer in the face of a France drifting ever further from its Catholic roots.

No papacy lasts forever, however. In these circumstances, the traditionalists of the SSPX might be best advised to profit from the freedom that the latitudinarian Francis has paradoxically allowed them. Tout est grâce, St Therese of Lisieux was noted for saying, even perhaps the proffered hand of a liberal pope.

\section{Bibliography}

Airiau, P (2009) Le Séminaire de Rome. Histoires et missions chrétiennes, no. 10, June: 33-68. 
Austermuehl, F. (2014) The Great American Scaffold : intertextuality and identity in American presidential discourse (Amsterdam : John Benjamins Publishing Company). Bastié, E (2015) La revolution silencieuse des catholiques de France. Le Figaro, 30

October. Available at: http://www.lefigaro.fr/actualite-france/2015/10/30/0101620151030ARTFIG00063-la-revolution-silencieuse-des-catholiques-de-france.php (accessed 28 November 2015).

Benedict XVI (2009) Letter to the Bishops of the Catholic Church concerning the remission of the excommunication of the four bishops consecrated by Archbishop Lefebvre (10 March). Available at: http://w2.vatican.va/content/benedictxvi/en/letters/2009/documents/hf ben-xvi let 20090310 remissionescomunica.html (accessed 13 October 2015).

Birnbaum, P (2006) The New Right. In: Kritzman, Lawrence D. and Reilly, Brian J. (eds) The Columbia History of Twentieth-Century French Thought. New York: Columbia University Press, pp. 69-73.

Bouchacourt, C (2015) Interview with the author, 10 October.

Celier, G (2007), Benoît XVI et les traditionalistes. Paris: Entrelacs.

Celier, G (2008) Un terreau fertile. Fideliter. No. 184. June-August: np.

Celier, G (2010) La courte honte d'un historien official, 30 October. Available at:

http://www.dici.org/documents/la-courte-honte-dun-historien-officiel/ (accessed 13 October 2015).

Chambart de Lauwe, P-H (1991) Vigilance: vieilles traditions extrémistes et droites nouvelles. Paris: Ligue des droits de l'homme. 
CICAD (2013) Propos anti-Juifs à Ecône, 8 February. Available at:

http://cicad.ch/fr/cicad-news-press-releases-and-feedback-anti-semitism-news-

press-releases-and-feedback/propos-anti (accessed 13 October 2015).

Colard, J-M and Moulène, C (2011) Le saccage du "Piss Christ", révélateur d'une

France haineuse, Les Inrocks, 18 April. Available at:

http://www.lesinrocks.com/2011/04/18/actualite/le-saccage-du-piss-christ-

revelateur-dune-france-haineuse-1116576/ (accessed 20 October 2015).

Congar, Y (1977) La Crise dans l'Eglise et Mgr Lefebvre. Paris: Cerf.

De Cacqueray, R (2005) Interview with Alain Sanders in Présent 9 March.

De Cacqueray, $R$ (2008), Lettre sur les vocations $n^{\circ} 16$, April. Available at:

http://laportelatine.org/publications/presse/2008/lettrevocations2008/vocations20

08.php (accessed 2 November 2015).

De Cacqueray, R (2010), Communiqué de l'abbé de Cacqueray - La mort des nations catholiques entraîne la disparition des minorités chrétiennes, 8 November. Available at:

http://laportelatine.org/district/france/bo/cacqueray101108/Cacqueray101108.php (accessed 30 October 2015).

De Cacqueray, R (2013a), Lettre aux Amis et Bienfaiteurs No. 80, June. Available at: http://laportelatine.org/district/france/lab district france/lab district france 801 306.pdf (accessed 30 October 2015).

De Cacqueray, R (2013b), Message du pape François pour la fin du Ramadan Dialogue avec I'Islam : notre cri d'alarme. Available at: http://laportelatine.org/vatican/sanctions indults discussions/27 juin 2013/02 08 2013 voeux pape francois fin du ramadan.php (accessed 29 November 2015). 
Dickès, J-P (2014) Civitas colloque: le compte rendu, Présent, 12 July.

Ennemond (2015) Interview with the author, 18 October.

Fellay, B (2011) Lettres aux amis et bienfaiteurs (No. 79), 21 December. Available at:

http://laportelatine.org/publications/bienfait/79/79.php (accessed 30 November 2015).

Fellay, B (2013) Lettres aux amis et bienfaiteurs (No. 81), 6 December. Available at: $\underline{\text { http://laportelatine.org/publications/bienfait/81/81.php (accessed } 30 \text { November }}$ 2015).

Fellay, B (2014) Lettres aux amis et bienfaiteurs (No. 82), 13 April. Available at:

http://laportelatine.org/publications/bienfait/82/82.php (accessed 3030 November 2015).

Fellay, B (2015) Lettres aux amis et bienfaiteurs (No. 84), 24 May. Available at: http://laportelatine.org/publications/bienfait/84/84.php (accessed 20 October 2015).

Figaro (2015) Taubira/Banania: I'abbé Beauvais relaxé, 19 May. Available at: http://www.lefigaro.fr/flash-actu/2015/05/19/97001-20150519FILWWW00257taubirabanania-l-abbe-beauvais-relaxe.php (accessed 30 November 2015).

Fouilloux, E (1997), Intégrisme catholique et droits de l'homme. In: Le Berre Jean (ed), Fondamentalismes, intégrismes. Une menace pour les droits de l'homme. Paris: Bayard Éditions/Centurion, pp. 11-27.

Greeley, A (2001) The Catholic Imagination (Jackson TN: University of California Press). 
Hoffner, A B and De Gaulmyn I (2010) 'La carte de France des prêtres', Le Figaro, 21 May. Available at: http://www.la-croix.com/Religion/Actualite/La-carte-de-Francedes-pretres- NG -2010-05-20-551782 (accessed 15 October 2015). John Paul II (1988) Ecclesia Dei, apostolic letter given motu proprio, 2 July. Available at:

(http://www.vatican.va/roman curia/pontifical commissions/ecclsdei/documents/h $\underline{f}$ ip-ii motu-proprio 02071988 ecclesia-dei en.html (accessed 13 October 2015). Lefebvre, M (1974) Conférences spirituelles données à Econe [unpublished manuscript].

Lefebvre, M (1976) J'accuse the concile. Martigny: Editions Saint Gabriel. Lefebvre, M (1985) Lettre ouverte aux catholiques perplexes. Paris: Albin Michel. Lefebvre, M (1987) Ils l'ont découronné. Paris: Editions Fideliter. Lefebvre, M (1989) Itinéraire spiritual. Paris: Editions Fideliter. Lefebvre, M (1999) Petite histoire de ma longue histoire: vie de Mgr Lefebvre racontée par lui-même. Paris: Soeurs de la Fraternité Saint Pie X. Le Floch, H (1927), letter in Le Gaulois, 4 December. Leo XIII (1891) Rerum novarum, encyclical letter, 15 May. Libération (2012) Enquête. Saint Nicolas-du-Chardonnet: avec foi mais sans loi, 11 May. Available at: http://www.liberation.fr/societe/2012/05/11/saint-nicolas-duchardonnet-avec-foi-mais-sans-loi 818169 (accessed 13 October 2015).

Michel, F (2009) L'Action française et l'intégrisme catholique: les paradoxes d'un antiromanisme ultraromain. In: Florian Michel et Bernard Sesboüé De Mgr Lefebvre à Mgr Williamson: anatomie d'un schisme. Paris: Lethielleux / Desclée de Brouwer, pp. 11-76. 
Nardi, G (2015) The Traditional Mass is Changing the Face of the French Clergy. In

The Eponymous Flower Blogspot. Available at:

http://eponymousflower.blogspot.co.uk/2015/11/the-traditional-mass-is-changingface.html?m=1 (accessed 27 November 2015).

Pius X (1905) I/ fermo proposito, encyclical letter of June 11.

Pius XI (1927) Apostolicorum in missionibus, papal decree of 14 December.

Porter, J (2005) Nature as Reason: A Thomistic Theory of the Natural Law. Eerdmans:

Grand Rapids.

Poulat, E (1985) La Querelle de l'intégrisme en France, Social Compass, 32(4): 343351.

Prévotat, J (2009), La condemnation de l'Action française et les Spiritains: le cas du Séminaire français, Histoires et mission chrétiennes, no. 10, June: 69-94.

Priest X (2015) Interview with the author, 14 October.

Rémond, R (1989) L’Intégrisme catholique. Portrait intellectual. Etudes, January 1989: 95-105.

Roberts, C (2000) Secularisation and the (re)formulation of French Catholic identity. In: Chadwick, Kay (ed) Catholicism, Politics and Society in Twentieth-Century France. Liverpool: Liverpool University Press, pp. 260-79.

Rostand, A (2015) Interview with the author, 12 October.

Sauvaget, B (2015) A cheval, Civitas veut “délivrer la France”, Libération, 10 May.

Available at: http://www.liberation.fr/societe/2015/05/10/a-cheval-civitas-veut-

delivrer-la-france 1304839 (accessed 30 October 2015).

Schein, E (1984) Coming to a new awareness of organizational culture. Sloan Management Review, 25(2): 3-16. 
Senèze, N (2012) Civitas, dans la mouvance du nationalisme catholique, La Croix, 19

November. Available at: $\underline{\text { http://www.la-croix.com/Religion/Actualite/Civitas-dans-la- }}$ mouvance-du-nationalisme-catholique- NG_-2012-11-19-877665 (accessed 16

October 2015).

Sudlow, B (2011) The untameable Provence of Charles Maurras, Nottingham French Studies, 50 (1): 19-30.

Tissier de Mallerais, B (2002) Marcel Lefebvre: une vie. Paris: Clovis.

Van Der Krogt, C (1992) Catholic Fundamentalism or Catholic Integralism. In: Veitch, James (ed) To Strive and Not to Yield: Essays in Honour of Colin Brown. Wellington (NZ): Victoria University of Wellington, pp. 123-135.

White, Owen and Daughton, J.P. (2012) In God's Empire: French Missionaries in the Modern World. Oxford: Oxford University Press.

${ }^{1}$ The exact remarks are available at: http://www.dailymotion.com/video/x2t3jzn (accessed 8 July 2016).

${ }^{2}$ Available at: http://laportelatine.org/accueil/accueil.php (accessed 29 November 2015). Unlike the superior general's letters, this collection of official letters by the French superior is not complete. The gaps are compensated for by the variety and date range of the other texts analysed. In this sense, the sample used is taken to be a representative sample of De Cacqueray's writings, though by no means an exhaustive one.

${ }^{3}$ For further details, see the statistics on the websites of the SSPX in France, available at: http://laportelatine.org/district/france/france.php (accessed 27 November 2015) and http://sspx.org/en/general-statistics-about-sspx (accessed 27 November 2015). 